\title{
Bench-scale assessment of three copper-based algaecide products for cyanobacteria management in source water
}

\author{
Elizabeth Crafton ${ }^{1,4} \cdot$ Jessica Glowczewski ${ }^{3} \cdot$ Teresa Cutright $^{1}$ (1) $\cdot$ Don Ott ${ }^{2}$
}

Received: 5 November 2020 / Accepted: 23 February 2021 / Published online: 28 February 2021

(C) The Author(s) 2021 OPEN

\begin{abstract}
Three copper-based algaecide products were investigated for use in a drinking water source to address cyanobacteria growth. Bench-scale experiments were used to determine the optimal dose of each product given Lake Rockwell's indigenous population and reservoir-specific characteristics. The optimal dose of Cutrine Ultra was determined to be a quarter dose (corresponding to $0.125 \mathrm{mg} / \mathrm{L} \mathrm{Cu}$ ) as it decreased $55 \%$ of the cyanobacteria population with limited release of microcystin and minimal rebound in the cyanobacteria population. The optimal dose for EarthTec was determined to be a half dose (i.e., $0.5 \mathrm{mg} / \mathrm{L})$. The full dose was optimal for SeClear $(1 \mathrm{mg} / \mathrm{L} \mathrm{Cu}$ ). The optimal doses had extracellular microcystin levels of $0.99 \pm 0.09 \mu \mathrm{g} / \mathrm{L}$ (quarter dose Cutrine Ultra), $3.69 \pm 0.43 \mu \mathrm{g} / \mathrm{L}$ (half dose EarthTec) and $0.92 \pm 0.26 \mu \mathrm{g} / \mathrm{L}$ (full dose SeClear) by day 2. EarthTec and Cutrine Ultra facilitated a similar overall response, and the cyanobacteria population was predominately suppressed in the initial 2 days following treatment and then increased between 7 and 14 days after treatment (i.e., rebound). Both the suppression within the first 2 days and the rebound between 7 and 14 days after treatment were a function of dose (e.g., lower dose, larger increase in rebound). Although SeClear suppressed the cyanobacteria population during the initial 2 days after treatment $(42,000 \pm 3240$ cells $/ \mathrm{mL}$ at the baseline to $4822 \pm 841)$, the cyanobacteria population rebounded significantly $(p<0.05)$ between 2 and 7 days after treatment.
\end{abstract}

Keywords Source water management $\cdot$ Algaecide $\cdot$ Cyanobacteria $\cdot$ Dolichospermum $\cdot$ Harmful algal blooms

\section{Introduction}

Cyanobacteria-dominated harmful algal blooms (cHABs) are growing in frequency in freshwater systems, especially in the Great Lakes region. cHABs pose a threat to human health through the biosynthesized toxins commonly associated with Microcystis and Dolichospermum (formerly identified as Anabaena) [26, 33]. The ability of these and other strains of cyanobacteria to synthesize cyanotoxins poses a significant threat leading the US Environmental Protection Agency (EPA) to place cyanotoxins on the contaminant candidate list. Although not all HABs are toxic, the excess biomass is still problematic for the aquatic system $[7,12,33]$. The frequency, magnitude, and toxicity of blooms are expected to increase as the impacts from climate change worsen $[20,26,31,35]$, indicating a critical demand to increase the understanding of $\mathrm{CHABs}$ and provide best management practices to ensure safe access to potable water. It is important to know the site-specific system parameters (i.e., nutrient levels, $\mathrm{pH}$, phytoplankton population dynamics, etc.) in order to provide effective decisions on managing a $\mathrm{CHAB}[24,26]$.

Immediate responses to $\mathrm{CHABs}$ are aimed at mitigating the impacts of an existing bloom or rising population

Supplementary Information The online version contains supplementary material available at https://doi.org/10.1007/s42452-021-04419 -5 .

Teresa Cutright, tcutrig@uakron.edu | ${ }^{1}$ Civil Engineering Department, University of Akron, Akron, OH, USA. ${ }^{2}$ Biology Department, University of Akron, Akron, OH, USA. ${ }^{3}$ Akron Water Supply, Kent, OH, USA. ${ }^{4}$ Present Address: Hazen and Sawyer, Columbus, OH, USA. 
with minimal adverse effect to the remaining biotic community. Algaecide treatment in source water is a common short-term management strategy $[23,37]$ to lessen the burden on the water treatment plant. There are many new and modified copper-based algaecides entering the market to meet the demand for mitigating CHABs. The EPA limits the maximum amount of copper $(1 \mathrm{mg} / \mathrm{L})$ that can be applied as the active ingredient as it is toxic to nontarget aquatic organisms $[4,20]$. The exact time that the copper will remain in the applied area and water column will depend on many factors (water chemistry, weather, etc.). Laboratory and field studies have found that the $\mathrm{Cu}^{2+}$ concentration is elevated within the water column for only $2-3 \mathrm{~h}[20,21]$. The $\mathrm{Cu}^{2+}$ ion interacts with aqueous carbonate and biocarbonate ions to form a copper carbonate precipitant that drops out of the water column $[9,30]$. Once aqueous copper concentrations return to background (i.e., pretreatment) levels, planktonic growth resumes. The algae killed by the algaecide will release nutrients from decaying cells or by reducing oxygen that release nutrients from sediments $[3,5]$ that can promote growth of other algae and phytoplankton. The new algae can promote subsequent zooplankton growth, which act as a natural algal and cyanobacterial suppressant. However, these zooplanktons are 10 times more sensitive to copper than phytoplankton [14].

The long-term use of copper-based algaecides in large quantities increases the risk of eco-toxicological affects and copper accumulation in the sediment $[20,28]$. Copper accumulation in sediment can be problematic, since concentrations as low as $40 \mu \mathrm{g} / \mathrm{L}$ exhibit a toxic effect on fish [20] and $60 \mathrm{mg} / \mathrm{kg}$ copper was toxic to 22 different prokaryotes [29]. The adverse risks of copper accumulation in sediments from algaecide applications are greatly influenced by site-specific sediment characteristics (sediment type, biogeochemistry, organic content quantity/ quality, available ligands, etc.). For instance, a reservoir in southern USA that received algaecide copper-based algaecide treatments for decades depicted no significant ecological risks attributable to copper due to the limited bioavailability of copper in the sediments [15]. Algaecide dose should consider both controlling $\mathrm{CHABs}$ and the ecological impact. Bench-scale testing is a cost-effective way to assess different algaecide products and optimize dose to achieve the desired suppression of cyanobacteria while cost effectively minimizing adverse ecological effects. The objectives of the bench-scale experiments were to: (1) assess the efficiency of three copper-based algaecide products at a full dose (based on the product label), half dose, and quarter dose for use in a local drinking water reservoir. The hypothesis is that lower doses will prove to be viable options and equally effective as the manufacturer's full recommended dose in addressing cyanobacteria population. (2) Investigate the potential release of intracellular microcystins as a result of algaecide application with respect to product and dose. It is hypothesized that the specific algaecide type and dose will induce different rates of release of toxins.

\section{Materials and methods}

\subsection{Algaecide sources and doses}

All three of the algaecides used in the study are approved for drinking water (e.g., NSF/ANSI certified). In addition, two of the algaecides, Cutrine Ultra and EarthTec, have been used by several drinking water utilities in Ohio.

Cutrine Ultra (Arch Chemicals, Inc.) is $27.8 \%$ mixed copper ethanolamine emulsified complex which provides $9 \%$ metallic copper. The ethanolamine is used to prevent the precipitation of copper by carbonates. At the full manufacture's recommended dose of 1.2 gallons per acre-ft, the $0.4 \mathrm{mg} / \mathrm{L}$ copper concentration will effectively control filamentous, colonial algae and maintain proper copper concentration for minimum $3 \mathrm{~h}$ contact time [21]. It is very viscous ( $396 \mathrm{mPa} \mathrm{s}$ at $24^{\circ} \mathrm{C}$ ) and requires dilution prior to application. A 10:1 dilution was used based on the spray method used by the participating watershed. For this experiment, $76 \mu \mathrm{L}, 38 \mu \mathrm{L}$, and $19 \mu \mathrm{L}$ of Cutrine Ultra was used for the diluted full (i.e., $0.5 \mathrm{mg} / \mathrm{L} \mathrm{Cu}$ ), half $(0.25 \mathrm{mg} / \mathrm{L} \mathrm{Cu})$, and quarter dose $(0.125 \mathrm{mg} / \mathrm{L} \mathrm{Cu})$ reactors, respectively.

The active ingredient in EarthTec (Earth Science Laboratories, Inc) is $19.8 \%$ of chelated copper sulfate pentahydrate (5\% metallic copper). The full dose corresponds to 0.1 gallon of EarthTec per 6,000 gallons of water for $1.0 \mathrm{mg} / \mathrm{L}$ metallic copper concentration [8]. For this experiment, EarthTec was diluted 10:1 for spray application to yield a $270 \mu \mathrm{L}, 135 \mu \mathrm{L}$, and $67.5 \mu \mathrm{L}$ for the full (corresponding to $1 \mathrm{mg} / \mathrm{L} \mathrm{Cu})$, half $(0.5 \mathrm{mg} / \mathrm{L} \mathrm{Cu})$, and quarter dose $(0.25 \mathrm{mg} / \mathrm{L} \mathrm{Cu})$ reactors, respectively.

The SeClear (SePro Corporation) active ingredient is $16.2 \%$ copper sulfate pentahydate (4.1\% metallic copper). SeClear also includes a proprietary ingredient said to bind reactive phosphorus. The application rate for planktonic species is 1-6.5 gallons/acre-foot [27]. This corresponds to non-diluted application of $27 \mu \mathrm{L}, 13.5 \mu \mathrm{L}$, and $6.75 \mu \mathrm{L}$ for the full (i.e., $1 \mathrm{mg} / \mathrm{L} \mathrm{Cu})$, half $(0.5 \mathrm{mg} / \mathrm{L} \mathrm{Cu})$, and quarter dose $(0.25 \mathrm{mg} / \mathrm{L})$ reactors, respectively.

\subsection{Reservoir description and cyanobacteria collection}

Lake Rockwell is a two billion gallons drinking water reservoir on the Cuyahoga River in northeast Ohio. The reservoir 
is used to produce $~ 35$ million gallons/day of drinking water. A Wisconsin Phytoplankton sampler (Model WILDCO 40-A37, $53 \mu \mathrm{m}$ mesh) was used to collect and physically concentrate the phytoplankton throughout the reservoir. Source water was collected from 1 foot below the water surface at the same time to account for reservoir-specific characteristics as water chemistry will impact algaecide effectiveness [10]. In addition, Lake Rockwell has an average turbidity unit of 3.22. Suspended solids/silt concentrations would not interfere subsequent algaecide effectiveness by binding the copper ions. Nutrient enrichment was not done to minimize abiotic changes (i.e., iron and carbonate concentrations) of the water which may alter the efficiency of treatment and to minimize changes in indigenous cyanobacteria [13].

\subsection{Experimental setup}

Although the Ohio EPA recommends applying algaecide in drinking water when cell counts reach 10,000 cells $/ \mathrm{mL}$ [25], each algaecide source and dosage were conducted using triplicate glass reactors with initial cyanobacteria populations of 40,000 cells $/ \mathrm{mL}$ in $1.6 \mathrm{~L}$ of raw source water. The 40,000 cells $/ \mathrm{mL}$ represents the maximum in-reservoir concentration that the specific watershed personnel will treat by algaecide due to the threat of release of intracellular organic matter associated with lysis or cell death. Baseline readings (i.e., before algaecide treatment) were taken prior to by amending the treatment reactors with either a full, half, or quarter dose of the algaecide. Control (no algaecide) and treatment reactors were quantified again at $1.5 \mathrm{~h}, 2,7$, and 14 days. Specific analysis conducted at each time step is described below. Experiments were conducted at room temperature $\left(25^{\circ} \mathrm{C}\right)$, under natural lighting conditions ( $14 \mathrm{~h}$ of light). A YSI Sonde (YSI 6600 V2) was equipped with two optical probes: phycocyanin (cells $/ \mathrm{mL}$ ) chlorophyll-a $(\mu \mathrm{g} / \mathrm{L})$ at each time step. The Sonde was also used to track temperature $\left({ }^{\circ} \mathrm{C}\right), \mathrm{DO}(\mathrm{mg} / \mathrm{L}), \mathrm{pH}$, conductivity $(\mu \mathrm{S} / \mathrm{cm})$, and total dissolved solids (TDS, $\mathrm{g} / \mathrm{L}$ ).

\subsection{Visual quantification and identification of cyanobacteria}

Plankton counts with a Palmer-Maloney counting chamber (400x) were performed to obtain the genera-based composition of the population at baseline, day 2, day 7 , and day 14 . After gentle mixing, a sterile pasture pipette was used to draw $5 \mathrm{~mL}$ from the middle of the water column. One and a half $\mathrm{mLs}$ was transferred to the self-closing chamber and left to settle for $15 \mathrm{~min}$. Once settled, four transects were counted per chamber [19] using an Olympus microscope (Model: BX50F, eyepiece: 10x/22). It is important to note that evaluating algal assemblages can be difficult. Therefore, multiple algal cell methods (e.g., phycocyanin and chl-a from the sonde) were used in conjunction with hand counts as tools to discern differences in the treatment methods. As samples were not stained, viability of cells was limited to identifying "dead cells" as those that had lysed. A more rigorous determination of cell viability can be addressed in future experiments in order to correlate algal population and microcystin concentration.

\subsection{Quantification of extracellular microcystin}

Extracellular microcystin concentration $(\mu \mathrm{g} / \mathrm{L})$ was quantified using a laboratory certified in the Ohio EPA-approved ELISA method. Ten $\mathrm{mL}$ sample was filtered through a $0.45 \mu \mathrm{m}$ filter and placed in an amber vial with thiosulfate to quench any residual oxidant before being sent for analysis. Extracellular microcystin was quantified baseline (i.e., pre-algaecide) and $1.5 \mathrm{~h}$ and 2 days after algaecide was applied.

\subsection{Correlating phycocyanin $\mu \mathrm{g} / \mathrm{L}$, cells $/ \mathrm{mL}$, and hand counts}

The YSI Sonde does an internal calibration using data from phycocyanin, chlorophyll-a, temperature, and conductivity probes. The specific YSI Sonde used in this study provided output for cyanobacteria in cells $/ \mathrm{mL}$. Hand counts [19] were performed to evaluate which organisms were present and to assess population changes throughout the experiments, as the sonde does not distinguish between species. Although the sonde can distinguish cells higher than 250,000 cells $/ \mathrm{mL}$, the correlation between the sonde and hand counts was conducted only for $\leqq 35,000 \pm 5000$ cells $/ \mathrm{mL}$ for this experiment. Supplemental Figure 1 contains the correlation between the hand count cell units $(\mathrm{CU}) / \mathrm{mL}$ and sonde cells $/ \mathrm{mL}$. It was found that the sonde can underestimate cells $/ \mathrm{mL}$ when Aphanizomenon was the dominant species present when the colony was not disaggregated before measurement. Changes in cyanobacterial population are reported in cells $/ \mathrm{mL}$ to remain consistent with the unit used by the Ohio EPA to measure algal bloom intensity. The World Health Organization also expresses alert levels of the severity and probability of health effects in terms of cells $/ \mathrm{mL}$ [17].

\subsection{Statistical analysis}

The main factors are dose $(\mathrm{mg} / \mathrm{L}$-active ingredient at 4 levels) and time (5 levels-baseline, 1.5 h, 2, 7, and 14 days). Each response (cyanobacteria, extracellular microcystin, and chlorophyll-a) was evaluated by a twoway ANOVA (Type III SS) coupled with Tukey's comparisons. A Pearson's correlation coefficient was also obtained 
for cyanobacteria and extracellular microcystins to assess the strength of the relationship between the two variables.

\section{Results and discussion}

\subsection{Bench-scale results of cyanobacteria suppression with Cutrine Ultra}

The recommended action level provided by the OEPA is 10,000 cells $/ \mathrm{mL}$; therefore, the goal of algaecide treatment is population suppression below 10,000 cells $/ \mathrm{mL}$ [25]. At the start of the Cutrine Ultra experiment, the dominant species (i.e., > 70\%) present in each reactor were Planktothrix and Pseudanabaena (see Supporting Table 1 for visual quantification of genera at each sampling interval). After treatment with Cutrine Ultra (Fig. 1a) the cyanobacteria population was below the 10,000 cells/mL action level; with the larger dose yielding a larger observed decline. From the baseline to 2-day interval, reactors treated with a full dose $(0.5 \mathrm{mg} / \mathrm{L} \mathrm{Cu})$ declined $91 \%$ from 39,986 $( \pm 3478)$ cells $/ \mathrm{mL}$ to $3,519( \pm 354)$ cells $/ \mathrm{mL}(p<0.05)$. The cyanobacteria in half dose $(0.25 \mathrm{mg} / \mathrm{L} \mathrm{Cu})$ reactors declined $64 \%$ from 37,324 ( \pm 490$)$ cells $/ \mathrm{mL}$ to 13,386 ( \pm 4102$)$ cells/ $\mathrm{mL}(p<0.05)$, and quarter dose $(0.125 \mathrm{mg} / \mathrm{L} \mathrm{Cu})$ reactors declined $53 \%$ from 40,427 ( \pm 3528 ) cells $/ \mathrm{mL}$ to 18,957 $( \pm 1,761)$ cells $/ \mathrm{mL}(p<0.05)$. However, the control increased by $2 \%$ from the baseline to 2 -day $(p>0.05)$. From the baseline to 2-day time interval, the genera-based dominance did not change. From these results, the decline in the cyanobacteria population was attributed, and proportional to, the dose given.
Fig. 1 Changes in a cyanobacteria versus time and $\mathbf{b}$ chl-a versus time with respect to dose of Cutrine Ultra. Full, half, and quarter dose corresponds to $0.5 \mathrm{mg} / \mathrm{L} \mathrm{Cu}, 0.25 \mathrm{mg} / \mathrm{LCu}$, and $0.125 \mathrm{mg} / \mathrm{L} \mathrm{Cu}$, respectively. Data were collected from an YSI Sonde. Error bars \pm one standard deviation of triplicate samples
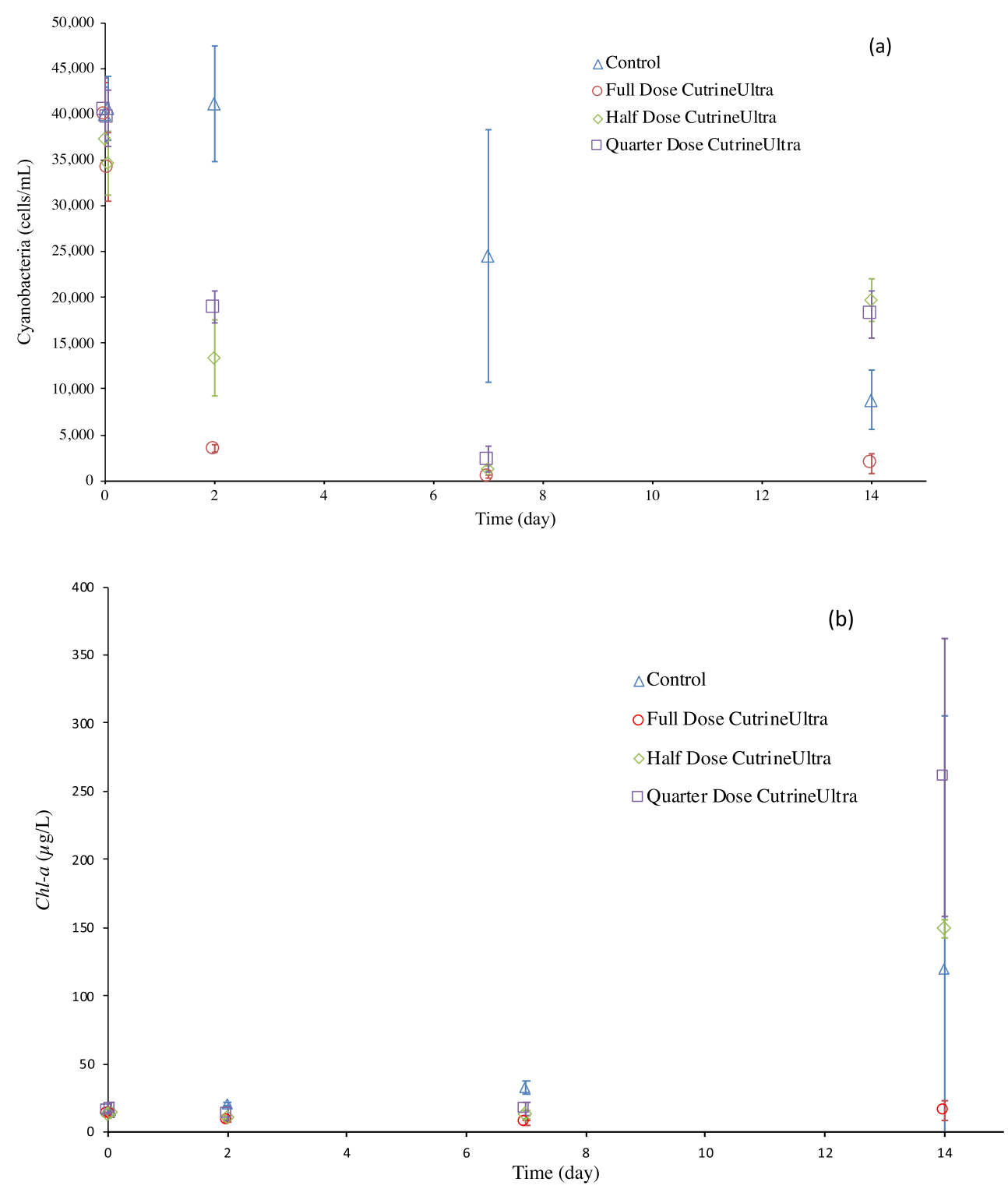
The cyanobacteria level in reactors treated with a full dose of Cutrine Ultra declined an additional $87 \%$ from 2 to 7-day. Half $(p<0.05)$ and quarter $(p<0.05)$ dose reactors also continued to decline $89 \%$ and $88 \%$, respectively, from 2 to 7 days. The Cutrine Ultra manual states full impact of treatment should be observed 7 days after application, and this was observed in the bench-scale experiments. The composition of the cyanobacteria population remained partially dominated by Planktothrix sp. in the full dose reactors. The composition in the half and quarter dose reactors, as well as control reactors, shifted from Planktothrix sp. and Pseudanabaena sp. to largely Raphidiopsis sp. and Pseudanabaena sp.

The cyanobacteria content in the control reactors did decrease over the 14 days. This was expected as the batch reactors were not amended with nutrients. The reactors treated with a full dose depicted a rebound (i.e., increase in cyanobacteria concentration attributed to new growth) in cyanobacteria of approximately $315 \%$ from 7 to 14 days. Cyanobacteria levels in the half dose reactors increased $1414 \%(p<0.05)$ and quarter dose reactors increased $827 \%(p<0.05)$ from 7 to 14 days. The genera that were dominant at 14 days were of a lower cell density in comparison with the commonly cited genera, such as Planktothrix, Anabaena, and Microcystis [33]. This may be a result of the controlled conditions and batch reactors. Calomeni et al. [4] also reported a significant increase in the algal mass between 7 and 14 days after treatment, which differed from the untreated control.

At 14 days, the dominant species were Raphidiopsis sp., Planktothrix sp., and Pseudanabaena sp., with Planktothrix $\mathrm{sp}$. declining the most in all reactors. The reactors treated with half $(0.25 \mathrm{mg} / \mathrm{L} \mathrm{Cu})$ and quarter dose $(0.125 \mathrm{mg} / \mathrm{L} \mathrm{Cu})$, as well as the control showed a dominance of Raphidiopsis sp. at 14 days. A shift in dominance is a function of batch reactors as no additional cyanobacteria entered the treated volume of water; unlike field conditions. However, a shift in dominance to Raphidiopsis sp. is ideal as it has not been identified as a toxin producer [33].

The chlorophyll-a (chl-a) content in reactors (Fig. 1b) treated with a full dose of Cutrine Ultra did not change significantly from 7 to 14 days $(p>0.05)$. Conversely, chl-a in reactors treated with half and quarter dose Cutrine Ultra increased $1,050 \%(p<0.05)$ and $1421 \%(p<0.05)$ from 7 to 14 days, respectively. It is difficult to directly compare the chl-a results to other research as chl-a is present all photosynthetic phytoplankton (e.g., target cyanobacteria and non-target green algae). Nonetheless, the increase is consistent with the trend observed by other researchers $[1,4]$. Bishop et al. [2] attributed the trend to the mode of action in ethanolamine-chelated copper algaecide being more selective toward cyanobacteria than non-target species.
The experiments with Cutrine Ultra all contained similar extracellular microcystin concentrations at the baseline condition $(p<0.05)$. The control reactors exhibited a decline from the baseline to the 2 days ( $p>0.05$, Table 1 ). The extracellular microcystin concentration increased $254 \%$ from the baseline to 2 days after treatment in reactors amended with a full dose of Cutrine Ultra $(p<0.05)$. The reactors treated with a half and quarter dose of Cutrine Ultra also had significant increase in extracellular microcystin from the baseline to 2 days, of $177 \%(p<0.05)$ and $171 \%(p<0.05)$, respectively.

The trend of extracellular toxins increasing with algaecide dose was expected. Microcystins are produced during the exponential growth phase and are stored in the intracellular organic matter (IOM) ( 90-95\% of total concentration) under favorable growth conditions with cyanotoxin release occurring during cell senescence, death, and lysis [34, 37]. From these results, Cutrine Ultra application released IOM and increased extracellular microcystin concentration. Pearson correlation coefficient for cyanobacteria and extracellular microcystins showed a strongly, negative correlation of -0.869 (Supporting Figure 2a). Kinley et al. [18] also observed the release of intracellular microcystins upon exposure to copper-based algaecide product. Iwinski et al. [15] observed the same strong negative correlation between cyanobacteria population and release of intracellular microcystin, thus increasing the extracellular microcystin concentration.

The highest dose cannot be arbitrarily chosen to treat the cyanobacteria population, as it greatly impacted the amount of microcystin released, which places an additional burden on the water treatment plant and ecologically on non-target organisms. The half dose had less of an impact of the remaining photosynthetic community and lower extracellular microcystin concentration. However,

Table 1 Extracellular Microcystin ( $\mu \mathrm{g} / \mathrm{L})$ obtained during batch algaecide experiments

\begin{tabular}{lllll}
\hline & & Cutrine Ultra & EarthTec & SeClear \\
\hline Control & Baseline & $0.53 \pm 0.12$ & $0.36 \pm 0.02$ & $0.50 \pm 0.19$ \\
& $1.5 \mathrm{~h}$ & $0.50 \pm 0.10$ & $0.34 \pm 0.07$ & $0.45 \pm 0.19$ \\
& 2 days & $0.40 \pm 0.17$ & $0.41 \pm 0.05$ & $0.41 \pm 0.10$ \\
Full & Baseline & $0.42 \pm 0.02$ & $0.27 \pm 0.07$ & $<0.3$ \\
& $1.5 \mathrm{~h}$ & $0.43 \pm 0.001$ & $0.72 \pm 0.08$ & $0.30 \pm 0.07$ \\
& 2 days & $1.49 \pm 0.45$ & $3.69 \pm 0.43$ & $0.92 \pm 0.22$ \\
Half & Baseline & $0.39 \pm 0.19$ & $0.28 \pm 0.03$ & $0.58 \pm 0.25$ \\
& $1.5 \mathrm{~h}$ & $0.43 \pm 0.20$ & $0.55 \pm 0.15$ & $0.45 \pm 0.27$ \\
& 2 days & $1.03 \pm 0.24$ & $3.47 \pm 0.49$ & $0.93 \pm 0.26$ \\
Quarter & Baseline & $0.37 \pm 0.004$ & $0.27 \pm 0.03$ & $0.70 \pm 0.17$ \\
& $1.5 \mathrm{~h}$ & $0.37 \pm 0.03$ & $0.36 \pm 0.08$ & $0.59 \pm 0.11$ \\
& 2 days & $0.99 \pm 0.09$ & $2.77 \pm 0.19$ & $1.04 \pm 0.43$ \\
\hline
\end{tabular}


it had the highest rebound at 14 days. Despite half and quarter dose being similar, quarter dose of Cutrine Ultra was chosen as it exhibited the smallest 14-day rebound.

\subsection{Bench-scale results of cyanobacteria suppression with EarthTec}

Dolichospermum, Microcystis sp., Planktothrix sp., and Pseudanabaena sp. were the dominant species at the start of the experiment. (Supporting Table S2 has the list of top four genera.) Significant differences were observed in the cyanobacteria content for all conditions (Fig. 2a). As anticipated, the reactors treated with a full dose of EarthTec $(1 \mathrm{mg} / \mathrm{L} \mathrm{Cu})$ declined significantly $(p<0.05)$ from the baseline to 2-day time interval. The cyanobacteria levels in the control reactors showed minimal changes from the baseline population of $44,371 \pm 648$ cells $/ \mathrm{mL}$ to the 2 -day cyanobacteria population of $42,646 \pm 1,134$ cells $/ \mathrm{mL}$

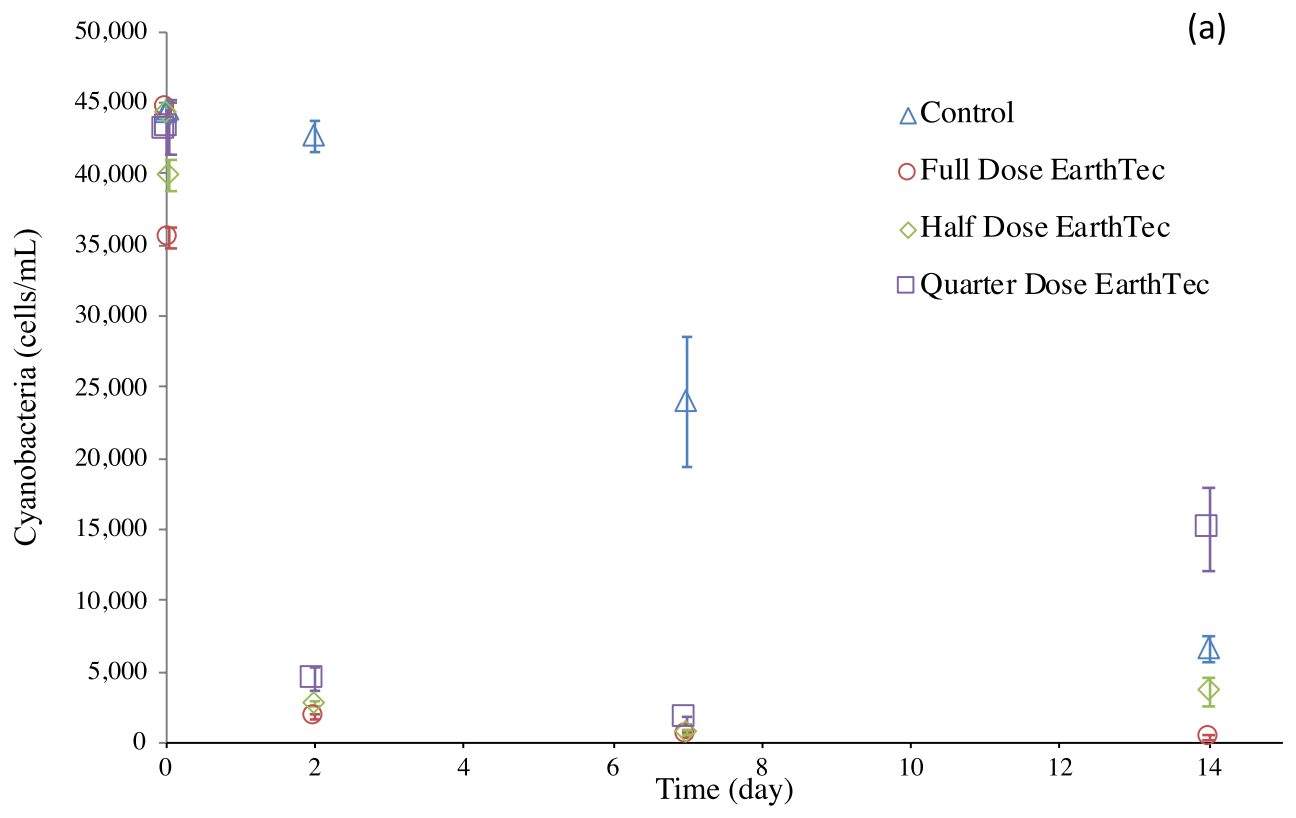

(b)

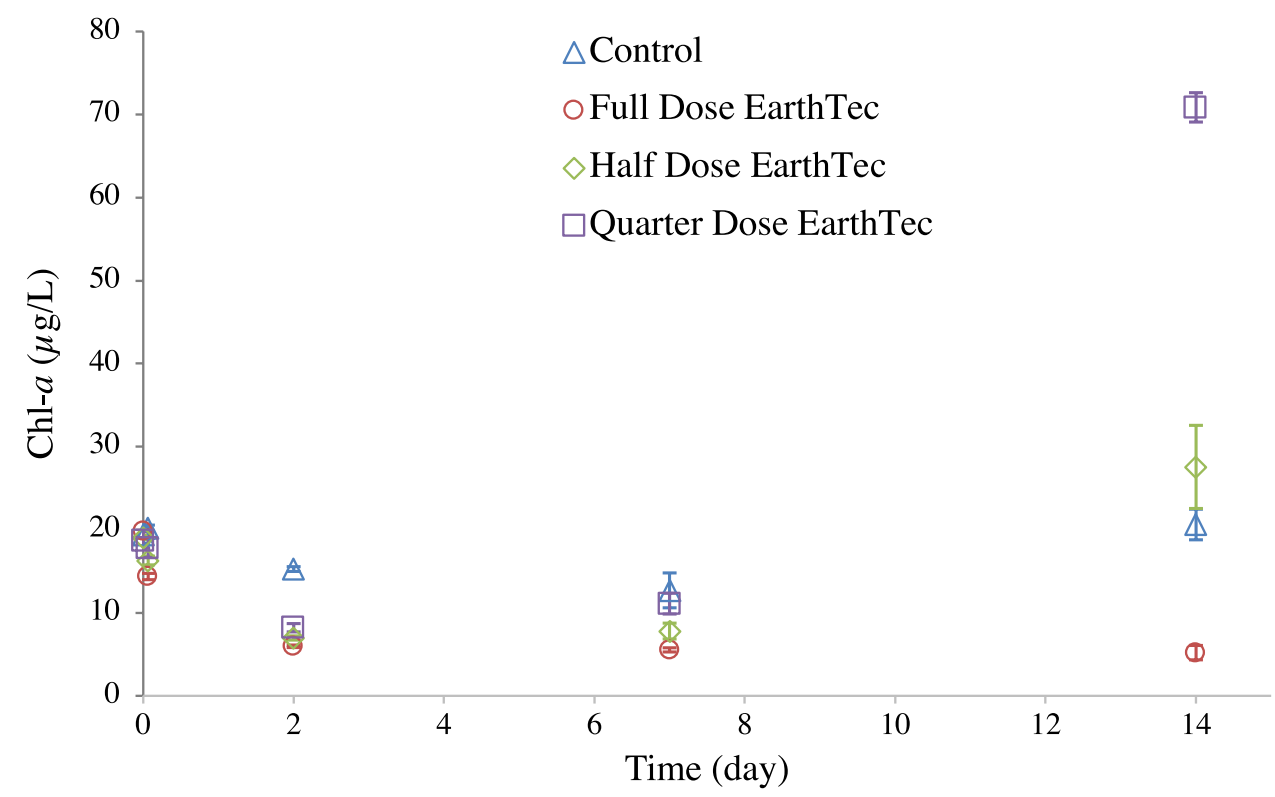

Fig. 2 Changes in a cyanobacteria versus time and $\mathbf{b}$ chl-a versus time with respect to dose of EarthTec. Full, half, and quarter

Cu, respectively. Data were collected from an YSI Sonde. Error dose corresponds to $1.0 \mathrm{mg} / \mathrm{L} \mathrm{Cu}, 0.5 \mathrm{mg} / \mathrm{L} \mathrm{Cu}$, and $0.25 \mathrm{mg} / \mathrm{L}$ bars \pm one standard deviation of triplicate samples 
$(p>0.05)$. Therefore, the algaecide treatment attributed to decline in the cyanobacteria populations.

The treated reactors did not exhibit significant activity from 2 to 7 days. From 7 to 14 days, the controls $(23,982 \pm 4651$ to $6602 \pm 970$ cells $/ \mathrm{mL}, p<0.05)$ and reactors treated with a full dose of EarthTec $(518 \pm 132$ cells $/ \mathrm{mL}$ to $374 \pm 132$ cells $/ \mathrm{mL}, p<0.05)$ continued to decline. The declining population in the control was attributed to a lack of sufficient nutrients Conversely, cyanobacteria in reactors treated with a quarter dose $(0.25 \mathrm{mg} / \mathrm{L} \mathrm{Cu})$ increased approximately $880 \%$ (1580 to 15,038 cells $/ \mathrm{mL}, p<0.05$ ). The cyanobacteria population in the half dose EarthTec $(0.5 \mathrm{mg} / \mathrm{L} \mathrm{Cu})$ reactors increased from 741 at 7 days to 3570 cells $/ \mathrm{mL}$ at 14 days after treatment. At 14 days, the dominant species (i.e., > 70\%) present in each reactor were Dolichospermum, Microcystis sp., Planktothrix sp., and Pseudanabaena sp., which was comparable to the baseline composition.

In comparison with the control at 2 days (Fig. 2b), there was a significant difference observed for chl-a concentration in full $(p<0.05)$, half $(p<0.05)$, or quarter $(p<0.05)$ dose groups. Considering the treated reactors declined significantly in a trend proportional to dose, the algaecide treatment might have impacted other members of the photosynthetic community. The impact of algaecide on non-target species is a largely understudied topic; however, eco-toxicological impact from copper sulfate has been well documented $[6,20,22,29]$. Reactors treated with half and quarter dose EarthTec depicted a rebound in chl-a of $254 \%(p<0.05)$ and $544 \%(p<0.05)$, respectively, from 7 to 14 days (Fig. 2b).

The extracellular microcystin concentration increased as the dose of EarthTec increased (Table 1). The content in control reactors was significantly different from each of the treated reactors $(p<0.05)$. From the baseline to the 2-day, the concentration within reactors treated with a full dose increased approximately $1347 \%(p<0.05)$. Extracellular microcystin concentration in reactors treated with half $(p<0.05)$ and quarter $(p<0.05)$ dose also increased, $1157 \%$ and $946 \%$, respectively. Pearson's correlation coefficient for extracellular microcystin and cyanobacteria was determined to be -0.984 (Supporting Figure $2 b$ ). Iwinski et al. [16] reported that $0.5 \mathrm{mg} / \mathrm{L}$ Cu released more intracellular microcystin than copper ethanolamine complex, with the difference attributed to the chelating agent. The results here demonstrated the copper delivery mechanism used could play a key role in release of intracellular microcystin.

A quarter dose of EarthTec $(0.25 \mathrm{mg} / \mathrm{L} \mathrm{Cu})$ was least successful in suppressing of cyanobacteria within 2 days of treatment and had the highest rebound from 14 days after treatment, despite not receiving additional nutrients. The full dose of EarthTec $(1 \mathrm{mg} / \mathrm{L} \mathrm{Cu})$ had the largest decline of the cyanobacteria and chlorophyll-a at 2 days as well as the largest extracellular microcystin concentration at the 2-day time interval. Therefore, it appeared the half dose was the most effective given the bench-scale data of EarthTec.

\subsection{Bench-scale results of cyanobacteria suppression with SeClear}

SeClear also has copper sulfate pentahydrate (16.2\%) as the active ingredient and contains a proprietary ingredient said to bind reactive phosphorus. The full dose was the maximum dose of $1 \mathrm{mg} / \mathrm{L}$ and was the EPA permit maximum. Dolichospermum, Microcystis sp., and Pseudanabaena sp. were the dominant species in each of the reactors at the start of the experiment. The full list of cyanobacteria species for at each time interval is provided in Supplemental Table S3.

There was a strong decline in cyanobacteria cells $/ \mathrm{mL}$ after algaecide application in the treated reactors, which appears proportional to the dose (Fig. 3a). The cyanobacteria in reactors treated with a full dose SeClear declined from 42,000 cells $/ \mathrm{mL}$ at the baseline to 4822 cells $/ \mathrm{mL}$ at 2 days after treatment $(p<0.05)$. Cyanobacteria level in the half dose reactors decreased $80 \%(41,980-8283$ cells $/ \mathrm{mL})$ 2 days after treatment $(p<0.05)$, while the cyanobacteria in the quarter dose declined approximately $61 \%$ between the baseline and 2-day time interval $(p<0.05)$. At day 2 , a significant difference was found between the control and full $(p<0.05)$, half $(p<0.05)$, or quarter $(p<0.05)$ doses. These results suggest a proportional dose impact of algaecide on the cyanobacteria population.

The population in reactors treated with a full dose declined only $12 \%$ from 2 to 7 -day $(p>0.05)$, while the cyanobacteria levels in half dose reactors increased approximately $186 \%$ and the population in the quarter dose reactors increased $145 \%(p<0.05)$. The half and quarter dose of SeClear may enable cyanobacteria to rebound sooner than the other copper-based products. The composition of the cyanobacteria population shifted to Pseudanabaena sp. dominant in all reactors and remained at 14 days.

Treated and control reactors did not exhibit any significant changes from 7 to 14 days. The minimal increase in the cyanobacteria level in reactors treated with a full dose of SeClear was similar to the rebound trend observed in half and quarter doses of both EarthTec and Cutrine Ultra. From 7 to 14 days, the cyanobacteria concentration in full dose Cutrine Ultra reactors increased $315 \%$ and full dose of EarthTec reactors decreased $21 \%$. This comparison was intriguing because the copper concentration in a full dose of either SeClear or EarthTec is $1 \mathrm{mg} / \mathrm{L} \mathrm{Cu}$ and shares the same active ingredient: copper sulfate pentahydrate. The copper concentration in a full dose of Cutrine Ultra 

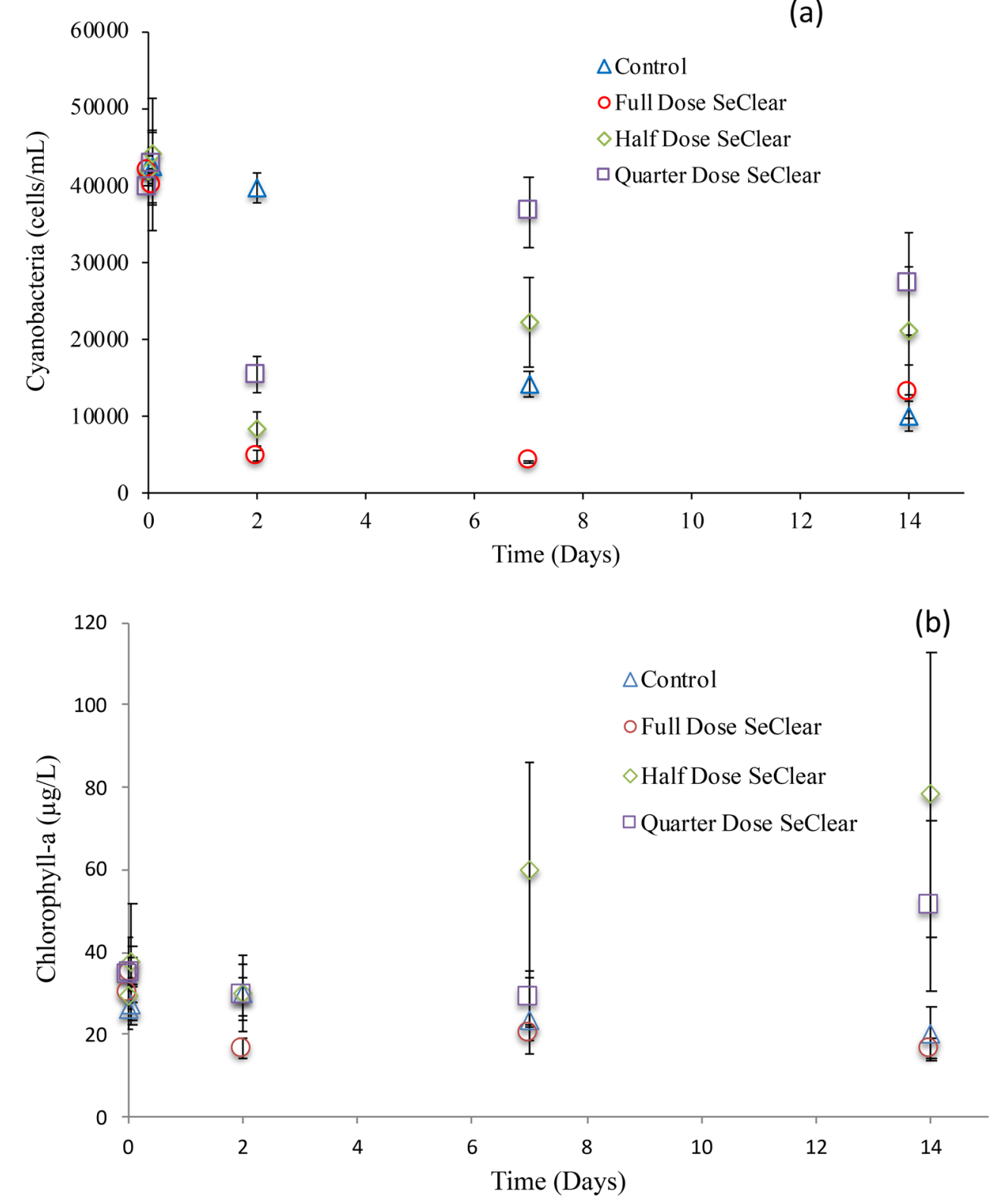

Fig. 3 Changes in a cyanobacteria versus time and $\mathbf{b}$ chl-a versus time with respect to dose of SeClear. Full, half, and quarter dose corresponds to $1.0 \mathrm{mg} / \mathrm{L} \mathrm{Cu}, 0.5 \mathrm{mg} / \mathrm{L} \mathrm{Cu}$, and $0.25 \mathrm{mg} / \mathrm{L}$

is $0.5 \mathrm{mg} / \mathrm{L} \mathrm{Cu}$ as copper ethanolamine complex. These results suggested that a full dose of SeClear might be less effective than a full dose of EarthTec. The difference in the cyanobacteria community could play a role. While there are a lot of similarities between the dominance, Planktothrix was not present during the SeClear experiments but was present in the EarthTec experiments. This was attributed to an artifact of when the samples were collected. Due to fluctuations across reactors, no significant changes in chl-a concentration were observed in the treated or control reactors $(p>0.05)$. For instance, from the baseline to
$\mathrm{Cu}$, respectively. Data were collected from an YSI Sonde. Error bars \pm one standard deviation of triplicate samples

2-day time interval the control increased approximately $14 \%$, full dose declined $44 \%$, half increased $1 \%$, and quarter dose declined $14 \%$ (Fig. 3b).

The extracellular microcystin in the reactors treated with SeClear appears to be moderately proportional to the dose given (Table 1). From the baseline to the 2 day, the reactors treated with a full dose of SeClear had an extracellular microcystin concentration increase of $222 \%(p<0.05)$. The reactors treated with half and quarter dose did not have significant increases $(p>0.05)$ nor did the control reactors change significantly change from the baseline 
to 2 days. The Pearson's correlation coefficient was determined to be -0.73 (Supporting Figure 2c). This same trend was observed in Cutrine Ultra and EarthTec experiments: EarthTec (-0.98), Cutrine Ultra $(-0.87)$, SeClear $(-0.73)$. SeClear's phosphorous binding agent could play a key role in the release of intracellular microcystin. For instance, Vezie et al. [32] found that in nitrogen rich water, intracellular microcystin concentration decreased when phosphorous concentration was low. Conversely, the binding agent may interact with the copper, which may minimize the bioavailability of the copper. The impact of the binding agent could not be discussed as it is a proprietary ingredient.

The quarter dose was least effective at 2-,7-, and 14-day time intervals. The cyanobacteria population in half dose reactors showed a higher rebound than the full dose reactors. Therefore, the full dose of $1.0 \mathrm{mg} / \mathrm{L}$ was selected as the optimal dose and is the highest allowed concentration.

\subsection{Comparison of copper products}

Copper concentration was held constant at $0.25 \mathrm{mg} / \mathrm{L}$ Cu to compare the copper-based products. The half dose of Cutrine Ultra corresponded to $0.25 \mathrm{mg} / \mathrm{L} \mathrm{Cu}$, whereas $0.25 \mathrm{mg} / \mathrm{L}$ was the quarter dose for EarthTec and SeClear. Differences among the cyanobacteria communities may play a role in the differences in averages and standard deviations. The main factors of time $(p<0.05)$ and presence of copper at $0.25 \mathrm{mg} / \mathrm{L} \mathrm{Cu}$ in treated reactors $(p<0.05)$ and interaction $(<0.05)$ were determined to significantly impact the cyanobacteria population. The product $(p<0.05)$ used also significantly impacts the observed response in cyanobacteria (Fig. 4). The ability of these products to suppress cyanobacteria was not surprising as bioavailable copper has several modes of action. Depending on the specific organism, copper toxicity denatures enzymes, affects the permeability of the cell membrane, and can substitute magnesium in chlorophyll to decrease photosynthetic activity, phosphorous uptake, and nitrogen fixation [14, 22]. The products cyanobacteria suppression from baseline to 2 days was EarthTec (90\%), Cutrine Ultra (64\%), SeClear (61\%). Cutrine Ultra (half dose) and EarthTec (quarter dose) possess very similar trends with respect to suppression by day 7 . The effectiveness of Cutrine Ultra was attributed to its surfactant and ethanolamine complexes to alter copper ion properties to permit passive transport across biological membranes and be less reactive with water chemistry [3]. EarthTec is also chelated to reduce impacts to water chemistry and exerts toxicity by affecting cell membrane permeability and resulting in loss of potassium ions [8]. The functional group on the surfactant within Cutrine Ultra could have acted as a biotic ligand to enhance copper transport into the cell that could have interfered with cellular functions prior to cell death [11], temporarily leaving more viable cells than in reactors treated with EarthTec. Both Cutrine Ultra (1414\%) and EarthTec (880\%) had a similar trend in rebound (i.e., 7-14 days), whereas SeClear (145\%) rebounded sooner (i.e., 2-7 days) than the other products (Fig. 4). EarthTec and SeClear have the same active ingredient (copper sulfate pentahydrate) and were held at the same copper concentration for this analysis. This comparison suggested that SeClear's proprietary compound may hinder efficiency, particularly if the mode of action posed by copper to the specific cyanobacteria present interfered with the uptake of phosphorous. Although Cutrine Ultra and EarthTec behaved similarly during the rebound period

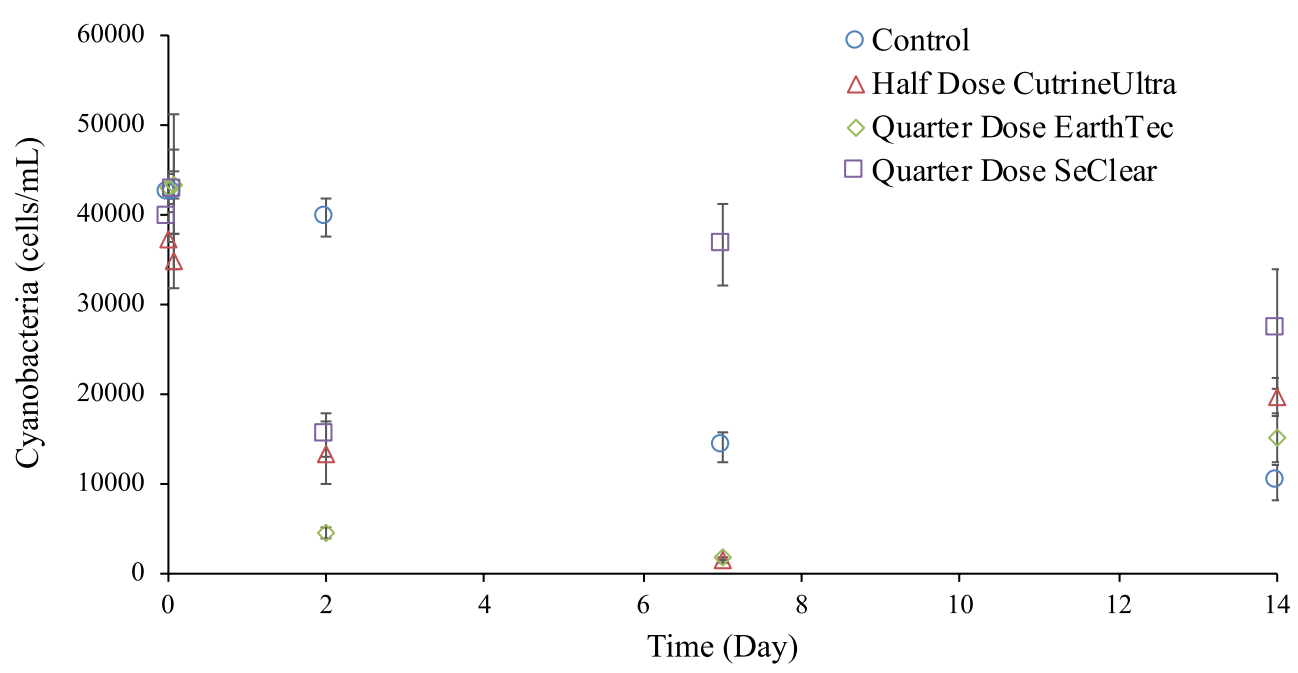

Fig. 4 Cyanobacteria versus time with respect to copper-based product, with the copper concentration held constant at $0.25 \mathrm{mg} / \mathrm{L} \mathrm{Cu}$. Data were collected from an YSI Sonde. Error bars \pm one standard deviation of triplicate samples 
with respect to timing (i.e., 7-14 day) and both exhibited a larger rebound compared to SeClear, the rebound occurred before the algaecide could be reapplied [27]. The EPA mandates a 14-day minimum interval between copper algaecide applications [36]. The fact that the cyanobacteria rebounded a week before potential reapplication when treated with SeClear would have significant impact on HAB management at quarter dose. In addition, SeClear was the most expensive of the algaecides even at a quarter dose. As shown in Table 2, using an 11-acre area and 4-foot depth for comparison a quarter dose of SeClear cost $\$ 1463$ for the 35.9 gallons needed. Cutrine Ultra, which was very effective at quarter dose, only costs $\$ 551$ for the needed 17 gallons.

\section{Conclusions}

Increasing frequency and intensity of $\mathrm{CHABs}$ have required research as to how much algaecide is needed to effectively suppress the bloom. Selection of the optimal dose was based on effective cyanobacteria suppression within two weeks, minimal rebound of cyanobacteria, limited release of extracellular microcystin, least reduction in $\mathrm{Chl}-\mathrm{a}$, and lower expected residual copper. Lower residual copper was based on the percent active ingredient applied at each dose and the possible need for reapplication. It is important to recall that although the same reservoir was used, reactors did contain the exact same population. For these experiments, the optimal dose of Cutrine Ultra was determined to be a quarter dose $(0.125 \mathrm{mg} / \mathrm{L} \mathrm{Cu})$. The optimal doses for EarthTec and SeClear were determined to be half dose $(0.5 \mathrm{mg} / \mathrm{L} \mathrm{Cu})$ and full dose $(1 \mathrm{mg} / \mathrm{L} \mathrm{Cu})$, respectively. EarthTec and Cutrine Ultra facilitated a similar overall response of the cyanobacteria population predominately suppressed in the initial 2 days following treatment and then increased between 7 and 14 days after treatment (i.e., rebound). Although SeClear effectively suppressed cyanobacteria, population rebounded after seven days, a week before reapplication would be permitted. Overall,

Table 2 Cost comparison and quantity needed for quarter dose algaecide application

\begin{tabular}{llll}
\hline & EarthTec & SeClear & Cutrine Ultra \\
\hline $\begin{array}{l}\text { Concentration of } \\
\text { active ingredient } \\
\text { (lb/gal) }\end{array}$ & 0.494 & 0.417 & 0.909 \\
$\begin{array}{l}\text { \$gal } \\
\text { Amount needed for } \\
\begin{array}{l}1 / 4 \text { dose (gallons) } \\
\text { Cost }\end{array}\end{array}$ & 30.3 & 40.75 & 32.38 \\
\hline
\end{tabular}

the quarter dose of Cutrine Ultra was determined the most effective-based cost and treatment performance.

\section{Supporting Information}

Correlation between hand counts to sonde cells $/ \mathrm{mL}$, visual identification of cyanobacteria at each time step, and Pearson's correlations.

Funding This work was supported by the Harmful Algal Bloom Research Initiative (Grant number 60054634) from the Ohio Department of Higher Education.

Data availability All relevant data are contained in the manuscript.

Declarations

Conflict of interest The authors have no conflict of interest.

Open Access This article is licensed under a Creative Commons Attribution 4.0 International License, which permits use, sharing, adaptation, distribution and reproduction in any medium or format, as long as you give appropriate credit to the original author(s) and the source, provide a link to the Creative Commons licence, and indicate if changes were made. The images or other third party material in this article are included in the article's Creative Commons licence, unless indicated otherwise in a credit line to the material. If material is not included in the article's Creative Commons licence and your intended use is not permitted by statutory regulation or exceeds the permitted use, you will need to obtain permission directly from the copyright holder. To view a copy of this licence, visit http://creativecommons .org/licenses/by/4.0/.

\section{References}

1. Bishop WM, Rodgers J Jr (2011) Response of Lyngbya magnifica gardner to an algaecide exposure in the laboratory and field. Ecotoxicol Environ Saf 74:1832-1838. https://doi.org/10.1016/j. ecoenv.2011.06.007

2. Bishop WM, Willis BE, Richardson RJ, Cope WG (2018) The presence of algae mitigates the toxicity of copper-based algaecides to a nontarget organism. Environ Toxicol Chem 37:2132-2142. https://doi.org/10.1002/etc.4166

3. Bishop WM, Villalon GV, Willis BE (2018) Assessing copper adsorption, internalization, and desorption following algaecide application to control Lyngbya wollei from Lake Gaston, NC/VA, USA. Wat Air Soil Pollut 229:152-161. https://doi.org/10.1007/ s11270-018-3801-6

4. Calomeni A, Iwinski K, Kinley C, McQeen A, Rodgers J Jr (2015) Responses of Lyngbya wollei to algaecide exposures and a risk characterization associated with their use. Ecotoxicol Environ Saf 116:90-98. https://doi.org/10.1016/j.ecoenf.2015.03.004

5. Cottingham KL, Ewing HA, Greer ML, Carey DD, Weathers KC (2015) Cyanobacteria as biological drivers of lake nitrogen and phosphorus cycling. Ecosphere 6:1-19. https://doi.org/10.1890/ ES14-00174.1

6. da Silva AF, da Cruz C, De Rezende FRL, Yamauchi AKR, Pitelli RA (2014) Copper sulfate acute ecotoxicity and environmental 
risk for tropical fish. Acta Sci Biol Sci 6:377-381. https://doi. org/10.4025/actascibiolsci.v3614.18373

7. Ding $S$, Chen $M$, Gong $M$, Fan X, Qin B, Xu H, Gao S, Jin Z, Tsang $D$, Zhang C (2018) Internal phosphorus loading from sediments causes season nitrogen limitation for harmful algal blooms. Sci Tot Environ 625:872-884. https://doi.org/10.1016/j.scito tenv.2017.12.348

8. EarthTec user manual, date accessed November 30 2017, www. epa.gov/pesticides/chem_search/ppls/064962-00001-30151 020.pdf

9. Elder JF, Horne AJ (1978) Copper cycles and $\mathrm{CuSO}_{4}$ algicidal capacity in two California lakes. Environ Manag 2:17-30

10. Fawaz EG, Salam DA, Kamareddine L (2018) Evaluation of copper toxicity using site specific algae and water chemistry: field validation of laboratory bioassays. Ecotoxicol Environ Saf 155:5965. https://doi.org/10.1016/j.ecoenv.2018.02.054

11. Geddie AW, Hall SG (2019) An introduction to copper and zinc pollution in macroalgae: for use in remediation and nutritional applications. J Appl Phycol 31:691-708. https://doi.org/10.1007/ s10811-018-1580-5

12. Gobler $C$, Burkholder J, Davis T, Harke M, Johengen $T$, Stow $C$, Van de Waal $D$ (2016) The dual role of nitrogen supply in controlling the growth and toxicity of cyanobacterial blooms. Harmful Algae 54:87-97. https://doi.org/10.1016/j.hal.2016.01.010

13. Graham JL, Loftin K, Meyer M, Ziefler A (2010) Cyanotoxin mixtures and taste-and-odor compounds in cyanobacterial blooms from the mid-western United States. Environ Sci Technol 44:7361-7368. https://doi.org/10.1021/es1008938

14. Greenfield DI, Duguette A, Goodson A, Keppler CJ, Williams SH, Brock LM, Stackley KD, White D, Wilde SB (2014) The effects of three chemical algaecides on cell numbers and toxin contents of the cyanobacteria Microcystis aeruginosa and Anabaenopsis sp. Environ Manage 54:1110-1120. https://doi.org/10.1007/s0026 7-014-0339-2

15. Iwinski KJ, McQueen AD, Kinley CM, Calomeni AJ, Geer TD, Rodgers JH (2016) Sediment copper concentrations, in situ benthic invertebrate abundance, and sediment toxicity: comparison of treated and untreated coves in a southern reservoir. Water Air Soil Pollut 227:85-95. https://doi.org/10.1007/s1127 0-016-2778-2

16. Iwinski K, Calomeni A, Geer T, Rodgers J Jr (2016) Cellular and aqueous microcystin-LR following laboratory exposures of Microcystis aeruginosa to copper algaecides. Chemosphere 147:74-81. https://doi.org/10.1016/j.chemosphere.2015.12.070

17. Jin C, Mesquita MMF, Deglint JL, Emelko MB, Wong A (2018) Quantification of cyanobacterial cells via a novel imaging-driven technique with an integrated fluorescence signature. Sci Rep 8:9055-9067. https://doi.org/10.1038/s41598-018-27406-0

18. Kinley C, Iwinski K, Hendrikse M, Geer T, Rodgers J Jr (2017) Cell density dependence of Microcystis aeruginosa responses to copper algaecide concentration: implications for microcystinLR release. Ecotoxicol Environ Saf 145:591-596. https://doi. org/10.1016/j.ecoenv.2017.08.010

19. Lawton L, Marsalek B, Padisák J, Chorus I (1999) Determination of cyanobacteria in the laboratory. In: Chorus I, Bartram J (eds) Toxic cyanobacteria in water. World Health Organization, E \& FN Spon, London, pp 347-67

20. Leal P, Moschini-Carlos V, Lopez-Doval J, Cintra J, Yamamoto J, Bitencourt M, Santos R, Abreu G, Pompeo M (2018) Impact of copper sulfate application at an urban Brazilian reservoir: a geostatistical and ecotoxicological approach. Sci Tot Environ 618:621-634. https://doi.org/10.1016/j.scitotenv.2017.07.095

21. Lonza (2017) Cutrine Ultra User Manual. www.Lonza.com. Accessed 30 Nov 2017. https://www.lonza.com/ /media/Files /water-treatment/Cutrine_Ultra.ashx?la=en
22. Matthijs HCP, Jancula D, Visser PM, Barsalek B (2016) Existing and emerging cyanocidal compounds: new perspectives for cyanobacterial bloom mitigation. Aquat Ecol 50:443-460. https://doi. org/10.1007/s10452-016-9577-0

23. Merel S, Walker D, Chicana R, Snyder S, Baures E, Thomas O (2013) State of knowledge and concerns on cyanobacteria blooms and cyanotoxins. Environ Internat 59:303-327. https:// doi.org/10.1016/j.envint.2013.06.013

24. Nwankwegu AS, Li Y, Huang Y, Wei J, Norgbey E, Sarpong L, Lai Q, Wang K (2019) Harmful algal blooms under changing climate and constantly increasing anthropogenic actions: the review of management implications. 3 Biotech 9:449. https://doi. org/10.1007/s13205-019-1976-1

25. Ohio EPA (2019) Public Water System Harmful Algal Bloom Response Strategy. https://epa.ohio.gov/Portals/28/documents/ habs/2019-PWS-HAB-Response-Strategy.pdf

26. Paerl H, Scott J, McCarthy M, Newell S, Gardner W, Havens K, Hoffman D, Wilhelm S, Wurtsbaugh W (2016) It takes two to tango: when and where dual nutrient reduction are needed to protect lakes and downstream ecosystems. Environ Sci Technol 50:10805-10813. https://doi.org/10.1021/acs.est.6b02575

27. SeClear user manual. www.SePro.com, Accessed 5 May 2018. https://sepro.com/documents/SeClear_Label.pdf

28. Simpson SL, Batley GE, Hamilton IL, Spadaro DA (2011) Guidelines for copper in sediments with varying properties. Chemosphere 85:1487-1495. https://doi.org/10.1016/j.chemospher e.2011.08.044

29. Sutcliffe B, Hose GC, Harford AJ, Midgely DJ, Greenfield P, Paulsen IT, Chariton AA (2019) Microbial communities are sensitive indicators for freshwater sediment copper contamination. Environ Pollut 247:1028-1038. https://doi.org/10.1016/j.envpo I.2019.01.104

30. Sylva RN (1976) The environmental chemistry of copper(II) in aquatic systems. Wat Res 10:789-792

31. Visser P, Verspagen J, Sandrini G, Stal L, Matthijs H, Davis T, Paerl $\mathrm{H}$, Huisman J (2016) How rising $\mathrm{CO}_{2}$ and global warming may stimulate harmful cyanobacteria blooms. Harmful Algae 54:145-159. https://doi.org/10.1016/j.hal.2015.12.006

32. Vezie C, Rapala J, Vaiomaa J, Seisonen J, Sivonen K (2002) Effect of nitrogen and phosphorous on growth of toxic and nontoxic Microcystis stains and on intracellular microcystin concentrations. Microbiol Ecol 43:443-454. https://doi.org/10.1007/20024 8-001-0041-09

33. Wehr JD, Sheath RG, Kociolek JP (2015) Freshwater algae of North America: ecology and classification. Elsevier, London

34. Wert E, Korak J, Trenholm R, Rosario-Ortiz F (2014) Effect of oxidant exposure on the release of extracellular microcystin, MIB, geosmin from three cyanobacteria species. Wat Res 52:251-259. https://doi.org/10.1016/j.watres.2013.11.001

35. Whitton BA, Potts M (2000) The ecology of cyanobacteria: their diversity in time and Sspace. Kluwer Academic, Dordrecht

36. United States Environmental Protection Agency (USEPA) (2009) Reregistration eligibility decision (RED) for coppers, EPA 738-R-09-304

37. USEPA (2014) Cyanobacteria and Cyanotoxins: information for drinking water Systems. Office of Water. www.EPA.gov.pdf

Publisher's Note Springer Nature remains neutral with regard to jurisdictional claims in published maps and institutional affiliations. 